\title{
SURGICAL DISEASE IN RURAL AREA; THE PATTERN OF SURGICAL DISEASE PREVALENT IN A RURAL AREA OF PAKISTAN
}

\author{
1. MD \\ General Prectitioner \\ East Tamworth NSW Australia. \\ 2. FCPS \\ Senior Registrar Surgery, \\ Allied Hospital, Faisalabad. \\ 3. MBBS \\ Medical Officer \\ Riaz Hospital, Faisalabad \\ 4. FRCS \\ Lahore. \\ Correspondence Address: \\ Dr. Faizan Riaz \\ Medical Officer \\ Riaz Hospital, Faisalabad \\ Article received on: \\ 24/01/2017 \\ Accepted for publication: \\ 22/05/2017 \\ Received after proof reading: \\ 05/06/2017
}

\section{INTRODUCTION}

Foundation Hospital Rajana is a classical welfare hospital run by a NGO based at Glasgow (UK). It is meant mostly for the poor or middle class rural population, District Toba Tek Singh of Punjab. This 75 bedded hospital is attached with a crowded outdoor, a well equipped laboratory and most modern radiology, ultrasound department and operation theatre.

It caters for gynaecology, obstetrical, medical, surgical, paediatric and neonatology cases. There are two gynaecologists, one paediatrician, one physician, one surgeon, one anaesthetist, one pathologist and one radiologist cum sinologist, four male medical officers and three women medical officers. A general surgeon takes all sort of surgical cases including minor trauma, gastroenterology, chest, breast hepatobiliary cases, thyroid, neck surgery, urology and cold orthopaedic. We do not have a department of acute trauma. The rural population comes to this hospital for all sort of ailment including surgical problems. We try to deal with them all locally to their satisfaction. We perform surgical operations under general, spinal, or local anaesthesia depending upon the type of surgery, fitness and preference of the patient. We do not perform the spinal, hip, cardiac, chest, complicated, maxillofacial and neuro surgery.

\section{MATERIAL AND METHODS}

All the cold cases presenting to the hospital are sorted out by receptionist for their speciality and sent to their respective outdoor. All the patients referred to the surgical department are seen by the author in the surgical OPD four days in a week. A detailed and quick history examination is undertaken and proper investigations like radiogram, Ultra sound or laboratory tests are asked for, which are carried out in the same hospital by latest machines by qualified personals. They are hospitalized if they need admission or treated as outdoor cases and prescribed the proper medicines. If their disease belongs to other specialities like gynaecology, obstetrics, paediatrics, or medicine they are referred to the proper hospital specialist.

\section{RESULTS}

\section{Sex and age (Table-I)}

Out of 8745 cases reported in surgical outdoor. 4724 were male 404 were female. The highest number of cases were between 21-50 years age group in males as well as in females. 


\section{Causes of Diseases (Table-II)}

The commonly specific causes were Trauma, Infection and Degenerative diseases. Malignant diseases are also not very uncommon. (Table-III)

\section{System Involved (Table-IV)}

Majority of cases belong to general surgery, followed by orthopaedic and trauma, Urological problems come in the third position.

\section{General Surgery (Table-V)}

Abdominal pathologies were the commonest followed by minor ailments, Head and neck, perineal (anorectal), breast cases are almost equal in number but much less.

\section{Orthopaedic (Table-VI)}

L.B.A was leading causes of disabilities followed by O.A of knees. Most of the amputations are due to diabetes mellitus (VII).

\section{Bone and Joint Injuries (Table-VIII)}

Fracture of Tibia and Femur were commonest followed by other bony injuries.

\section{Urology (Table-IX)}

Being enlargement of prostate is the commonest problem followed by the kidney stone.

\begin{tabular}{|l|c|c|c|}
\hline \multicolumn{1}{|c|}{ Age in years } & Male & Female & Total \\
\hline $0-10$ & $529(64.98 \%)$ & $285(35 \%)$ & 814 \\
\hline $11-20$ & $524(48.29 \%)$ & $561(51.70 \%)$ & 1085 \\
\hline $21-30$ & $840(47.32 \%)$ & $935(52.67 \%)$ & 1775 \\
\hline $31-40$ & $774(46.15 \%)$ & $903(53.84 \%)$ & 1677 \\
\hline $41-50$ & $703(48.01 \%)$ & $761(51.98 \%)$ & 1464 \\
\hline $51-60$ & $633(62.30 \%)$ & $383(37.6 \%)$ & 1016 \\
\hline $61-70$ & $448(75.9 \%)$ & $142(24.06 \%)$ & 590 \\
\hline Above 70 & $273(84.2 \%)$ & $51(15.74 \%)$ & 324 \\
\hline Total & $4725(54.03 \%)$ & $4021(48.03 \%)$ & 9619 \\
\hline
\end{tabular}

\begin{tabular}{|l|c|c|}
\hline \multicolumn{1}{|c|}{ Causes } & Number & Percentage \\
\hline Deformity & 408 & $4.66 \%$ \\
\hline Trauma & 1311 & $14.99 \%$ \\
\hline Infections & 1099 & $12.57 \%$ \\
\hline Tuberculos & 169 & $1.93 \%$ \\
\hline Degenerative & 855 & $9.77 \%$ \\
\hline Benign Growth & 644 & $7.36 \%$ \\
\hline Malignancy & 235 & $2.68 \%$ \\
\hline Others & 3067 & $35.07 \%$ \\
\hline Other specialties & 957 & $10.94 \%$ \\
\hline Total & 8745 & $99.97 \%$ \\
\hline
\end{tabular}

Table-II. Aetiology of the diseases

\begin{tabular}{|l|c|c|}
\hline \multicolumn{1}{|c|}{ Organ } & Numbers & Percentage \\
\hline Breast & 96 & $40.85 \%$ \\
\hline Gastrointestinal trace & 17 & $7.23 \%$ \\
\hline Lymph Glands & 30 & $12.76 \%$ \\
\hline Hepato Biliary & 21 & $8.93 \%$ \\
\hline Bones & 17 & $7.23 \%$ \\
\hline Head and Neck & 24 & $10.21 \%$ \\
\hline Uroc enital tract & 27 & $11.49 \%$ \\
\hline Other & 3 & $1.28 \%$ \\
\hline Total & 235 & $99.98 \%$ \\
\hline
\end{tabular}

Table-III. Cancers 


\begin{tabular}{|c|c|c|}
\hline System & Number & Percentage \\
\hline General surgery & 4094 & $46.81 \%$ \\
\hline Orthopedic and Trauma & 2315 & $26.47 \%$ \\
\hline Urology & 1266 & $14.47 \%$ \\
\hline Chest & 68 & $0.77 \%$ \\
\hline Neuro surgery & 45 & $0.51 \%$ \\
\hline Non-surgical & 957 & $10.94 \%$ \\
\hline Total & 8745 & $99.97 \%$ \\
\hline \multicolumn{3}{|c|}{ Table-IV. System involved } \\
\hline
\end{tabular}

\begin{tabular}{|c|c|c|c|c|}
\hline System & Disease & Number & Percentage of Surgery & Grand total \\
\hline \multirow{7}{*}{ Abdomen } & Hernias & 570 & $31.57 \%$ & \\
\hline & Call bladder & 537 & $29.75 \%$ & \\
\hline & Appendix & 451 & $24.98 \%$ & \\
\hline & DU & 87 & $4.81 \%$ & \\
\hline & Liver & 42 & $2.32 \%$ & \\
\hline & Perforations & 56 & $3.10 \%$ & \\
\hline & Obstruction & 62 & $3.43 \%$ & 1805 \\
\hline \multirow{4}{*}{ Head and Neck } & Goiter & 183 & $47.28 \%$ & \\
\hline & Lymph Glands & 118 & $30.49 \%$ & \\
\hline & Sallvary gand & 38 & $9.81 \%$ & \\
\hline & Others & 48 & $12.40 \%$ & 387 \\
\hline \multirow{5}{*}{ Perineal } & Piles & 140 & $40.57 \%$ & \\
\hline & Fistula & 100 & $28.98 \%$ & \\
\hline & Fissure & 60 & $17.39 \%$ & \\
\hline & Prolaps & 26 & $7.53 \%$ & \\
\hline & Rectal polyps & 19 & $5.50 \%$ & 345 \\
\hline \multirow{5}{*}{ Breast } & Cancer & 96 & $31.68 \%$ & \\
\hline & Benign tumor & 75 & $24.75 \%$ & \\
\hline & Dysplasia & 55 & $18.15 \%$ & \\
\hline & Infection & 55 & $17.49 \%$ & \\
\hline & Deformity & 24 & $7.92 \%$ & 303 \\
\hline Varicose vein & & 19 & $0.46 \%$ & 19 \\
\hline Minor disease & $\begin{array}{l}\text { Abcess infection cyst } \\
\text { tumor ulcer sinus }\end{array}$ & 1235 & $30.17 \%$ & 1235 \\
\hline Total & & 4094 & & 4094 \\
\hline \multicolumn{5}{|c|}{ Table-V. General Surgery } \\
\hline
\end{tabular}

\begin{tabular}{|l|c|c|}
\hline \multicolumn{1}{|c|}{ Disease } & Number & Percentage \\
\hline LBA & 722 & $47.15 \%$ \\
\hline OA knee & 258 & $16.85 \%$ \\
\hline OA other & 211 & $13.78 \%$ \\
\hline Deformity & 174 & $11.36 \%$ \\
\hline Amputations & 118 & $7.70 \%$ \\
\hline Infection & 31 & $2.02 \%$ \\
\hline New growth & 17 & $1.11 \%$ \\
\hline Total & 1531 & $99.97 \%$ \\
\hline
\end{tabular}




\begin{tabular}{|c|c|c|c|c|}
\hline \multicolumn{2}{|c|}{ Cause } & Number & & Percent \\
\hline \multicolumn{2}{|l|}{ DM } & \multicolumn{2}{|l|}{74} & $62.71 \%$ \\
\hline \multicolumn{2}{|l|}{ Trauma } & \multicolumn{2}{|l|}{39} & $33.06 \%$ \\
\hline \multicolumn{2}{|l|}{ Vascular diseases } & 5 & & $4.23 \%$ \\
\hline \multicolumn{2}{|l|}{ Total } & \multicolumn{2}{|l|}{118} & $100 \%$ \\
\hline \multicolumn{5}{|c|}{ Table-VII. Amputations } \\
\hline \multicolumn{2}{|c|}{ Disease } & \multicolumn{2}{|l|}{ Number } & Percentage \\
\hline \multicolumn{2}{|l|}{ Multiple } & \multicolumn{2}{|l|}{45} & $5.68 \%$ \\
\hline \multicolumn{2}{|l|}{ Tibia } & \multicolumn{2}{|l|}{130} & $16.43 \%$ \\
\hline \multicolumn{2}{|l|}{ Femor } & \multicolumn{2}{|l|}{129} & $16.30 \%$ \\
\hline Colles & & 55 & & $6.95 \%$ \\
\hline Humerous & & 48 & & $6.06 \%$ \\
\hline Radius & & 27 & & $3.41 \%$ \\
\hline Ulna & & 25 & & $3.16 \%$ \\
\hline Pelvis & & 22 & & $2.78 \%$ \\
\hline Small Bones & & 300 & & $37.92 \%$ \\
\hline Dislocation & & 10 & & $1.26 \%$ \\
\hline Total & & 791 & & $99.95 \%$ \\
\hline & & ble-VIII. Fractures & dislocation & \\
\hline Organs & Disease & Number & Percentage & Grand total \\
\hline & Stones & 358 & $28.27 \%$ & \\
\hline & Deformity & 20 & $1.57 \%$ & \\
\hline Kidney \& Ureter & Malignancy & 4 & $0.31 \%$ & \\
\hline & Infection & 48 & $3.87 \%$ & 430 \\
\hline & Stones & 71 & $5.60 \%$ & \\
\hline Bladder & Incontinence & 12 & $0.94 \%$ & \\
\hline & Malignancy & 12 & $0.94 \%$ & 95 \\
\hline Prostate & $\mathrm{BPH}$ & 387 & $30.56 \%$ & 387 \\
\hline & Stricture & 46 & $3.63 \%$ & \\
\hline Penis and uretra & Deformity & 42 & $3.31 \%$ & \\
\hline & Circumcision & 139 & $10.97 \%$ & 227 \\
\hline & Hydroce & 55 & $4.34 \%$ & \\
\hline & Varicocle & 19 & $1.50 \%$ & \\
\hline Scrotum and & UDT & 13 & $1.02 \%$ & \\
\hline & Infection & 35 & $2.76 \%$ & \\
\hline & Tumor & 5 & $0.39 \%$ & 127 \\
\hline Total & & 1266 & $99.98 \%$ & 1266 \\
\hline & & Table-IX. L & & \\
\hline
\end{tabular}

\section{DISCUSSION}

Surgical problems are increasing every day in the whole world and account for $11 \%$ of all diseases ${ }^{1}$ Pakistan has its share. $64 \%$ of population live in rural areas of Pakistan ${ }^{2}$ but nobody knows the exact prevalence and pattern of surgical diseases in this area. Toba Tek Singh district is a typical rural area where agricultural lands are fertile, there is no scarcity of water, climate is not very harsh and the people are not very poor. The period of this study is 20 months. This study include all subspecialties of surgery, through our Trauma cases do not really represent the local statistics, as we do not have acute trauma department in our hospital. We have excluded non-surgical cases in this study.

Male and female ratio is almost same in all the age groups except below 10 year and above 50 years where men dominate. In the first decade it 
is perhaps due to the Muslim custom to get the males circumcision in the early age but the cause of the older group could not be understood. perhaps due to prostatic enlargement in men.

In the known causes of the disease trauma is leading which goes in according to the study of Sohail ET $\mathrm{Al}^{3,4}$ followed by infections. Though malignant disease are not very common in this area but still we have our share. Leading malignancy in female population is breast cancer which goes in accordance to our national ${ }^{5,6}$ and world figure ${ }^{7}$ Breast cancer occurs 69.1 per 100,000 population in Pakistan which is equivalent to European and North America rate. ${ }^{8}$ Like worldwide prevalence the commonest symptom is low back aches. ${ }^{9,10}$ The commonest disease admitted for operation is abdominal hernia, followed by cholelcysteictomies.

Majority of our cases belong to general surgery which include abdominal pathologies, head and neck, perianal and rectal diseases, breast, varicose veins and minor surgical cases. It is followed by orthopaedics and trauma, urology, chest and neurosurgery. Abdominal hernia was the most common cases in general surgery, which goes in accordance to other regions of Pakistan. ${ }^{11,12}$ It is followed by cholelithiasis and appendicitis. Gallbladder disease comes third in Pakistan in other study..$^{13}$ Its incidence used to be 10 to $15 \%$ in west and 2 to $5 \%$ in Asia and African countries according to old studies in $1999^{14}$ but it is $10 \%$ in west and $17 \%$ in Asia. ${ }^{15}$ According to new study, $14-16 \%$ in Pakistan ${ }^{13}, 11.5 \%$ in Saudi Arabia. ${ }^{16}$

Appendicitis is number 3 in our study which goes against majority of study where it is most common operation performed in general surgery. ${ }^{17,18}$ Its incidence is 1.5-1.9 percent population of Pakistan ${ }^{19}$ in contrast to western standards where it occurs in $8.6 \%$ in males and $6.7 \%$ in female and highest incidence is between $22-26$ years of age. ${ }^{20}$

In head and neck surgery thyroidectomy is leading perhaps due to the fact that this area is stretched along River Ravi. ${ }^{21}$ Beside it is the common surgery of the neck done by general surgeon in the whole world ${ }^{22}$, its incidence is $5-12 \%$ in females $2-5 \%$ in males. ${ }^{23,24}$

Inperineal surgery piles are the leading morbidity in this area. According to Gencosmaniglu et al (25) $5 \%$ of the population of world and $50 \%$ after 50 years of age suffer from Piles, only $1 / 3 \%$ goes to the doctors. ${ }^{26}$

In orthopaedics, the commonest ailment is osteoarthritis if spine followed by knees and other joints. ${ }^{9,10}$ Amputation minor or major is not an uncommon operation where leading cause is diabetes mellitus in our series and in world literature ${ }^{27,28}$ though in some studies trauma is a leading cause. ${ }^{29}$ As far fracture of long bone are concerned, being superficial bone tibia is most commonly fractured followed by femur and colles which goes accordance to world literature. ${ }^{30,31,32,33,34}$

Prostate enlargement is a leading disease in urology in our study followed by urolithiasis. Common occurrence of prostate disease in Pakistan and whole word is due to growing aged population. ${ }^{35}$ Prostatic cancer is not very common in this area as compared to other area of Pakistan ${ }^{36}$ and world ${ }^{37}$ Urolithiasis is not uncommon with us but less common than hot and dry areas of Pakistan where scarcity of drinking water is real problem. ${ }^{3,38}$ It is also a third common problem in urology in most of the countries of the world. ${ }^{39}$ In scrotum hydrocele is the commonest problem with us followed by varicocele, which goes in accordance to Chukwadi et $\mathrm{al}^{40}$ and Siddique Et Al. ${ }^{41}$

\section{CONCLUSION}

Surgical disease account $11 \%$ of all medical problems. ${ }^{1}$ Their prevalence vary in different geographical areas, socially, ethnic and economic groups. ${ }^{42}$ In our series, the most common age group is between 30 to 50 years, the commonest cause of disease is Trauma, commonest disease is low backache and commonest operations are for Hernias followed by Gall bladder stone. 


\section{ACKNOWLEDGEMENT}

We are grateful to Mr. Yasir Salim and Mr. Athar Adrees for their statistical and secretarial help in preparing this manuscript.

Copyright@ 22 May, 2017.

\section{REFERENCES}

1. Basic surgery training to save lives and prevent disability. WHO, 2007. www.who.int/mediacentre/ mews/notes/2007.

2. Annual plan 2010-11, planning commission, Govt: of Pakistan: chapter 09, population and development. Available from www.planing commission.gov.pk.

3. Suhail MA, Lal B, Paryani JP, Shaikh Y. Rural surgery, Professional Med J 2013;20: 566-575.

4. Alvi R. Experience of developing rural surgical care in a remote mountainous region of Pakistan: Challenges and opportunities. Ann Top Med Public Health 2011; 4:57-63.

5. Muhammad N, Rafique M, Baloch S, Raza SH, Khan H, Qureshi S. Cancers; Sindh based prevalence, Professional Med J 2014;21: 123-129.

6. Bhurgri Y, Bhurgri A, Hassan SH, Zaidi SH, Rahim A, Sankaranarayanan R, Parkin DM. Cancer incidence in Karachi, Pakistan: First results from Karachi Cancer Registry, International J. Cancer, 2000, 85:325-329.

7. Maggi B, Hafeez H, Faisal S, Hassan M, Zafar A. The impact of culture and sociological and psychological issues on Muslim patients with breast cancer in Pakistan, cancer nursing, 2009; 32:1-8.

8. Canadian cancer society, advisory committee in cancer statistics. 2013 p15.

9. Jin K, Sorock GS, Courtney TK. Prevalence of low back pain in three occupational groups in Shanghai, PRC, J. Safety Res. 2004; 35:23-28.

10. Kraychete DC, Sakata RK, Issy AM, Santos-Jesus R, Carvalho EM. Serum cytokine levels in patients with chronic low back pain due to herniated disc. Sao Paulo Med J. 2010; 128:259-262.

11. Alam SN, Rehman S, Raza SM, Manzar S. Audit of a general surgical unit: Need for self evaluation. Pakistan journal of surgery 2007; 23(2):141-43.

12. Shaikh R,Jeddi MF,Ali G, Iqbal SA. Pattern of diseases in a surgical unit at Lyari General Hospital, Karachi. Med Channel 2000; 6(2):29-31.

13. Brohi S, Khan LZ, Shaikh U, Shaikh SU. Laparoscopic
Cholecystectomy, Professional Med. J. 2014; 21:601605.

14. Kratzer W1, Mason RA, Kächele V. Prevalence of gallstones in sonographic surveys worldwide, $\mathrm{J} \mathrm{Cl}$ Ultrasound. 1999; 27:1-7.

15. Festi D, Dormi A, Capodicasa S, Staniscia T, Attili A, et al. Incidence of gallstone disease in Italy, World J. Gastroenterol. 2008, 14; 5282-5289.

16. Abu-Eshy SA, Mahfouz AA, Badar A, El Gamal MN, AL Shehri MY, Salati Ml, et al. Prevalence and risk factors of gall stone disease in high attitude Saudi population. East Mediterr Health J. 2007; 13:794-802.

17. Tseng YC, Lee MS, Chang YJ, Wu HP. Acute abdomen in pediatric patients admitted to the pediatric emergency department. Pediatr Neonatol. 2008; 49:126-134.

18. Ditillo MF, Dziura JD, Rabinovici R. Is it safe to delay appendectomy in adults with acute appendicitis? Ann Surg. 2006, 244:656-60.

19. Malik KA, Khan A, Waheed I. Evaluation of the Alvarado score in diagnosis of acute appendicitis. J. Coll Physicians Surg Pak. 2000; 10:392-394.

20. Talukder DB. Modified Alvardo scoring system in the diagnosis of acute appendicitis, JAFMC Bangl. 2009, 5: 18-20.

21. Rathore AH, Ahmed G. Thyroidectomy for a Giant Goitre, Pak J. Surg. 1994, 10: 94-95.

22. Guraya SY, Al-Zobydi AH, Total and Near-total Thyroidectomy, A Prospective Analysis, Br. J. Med, 2011, 1:1-6.

23. Tahsin C, Akca T, Turkmenoglu, Canbaz H, Ustunsoy B, Kanik A, Aydin S. Drainage after total thyroidectomy, J. Zhejiang University Science, 2008, 9; 319-323.

24. Ahmad I, Sarwat, Rehan AG. Surgical management of multinodular goitre, Professional Med. J. 2014; 21: 535-539.

25. Gencosmanoglu R, Sad O, Koc D, Inceoglu R. Hemorrhoidectomy: open or closed technique? A prospective, randomized clinical trial, Dis Colon Rectum, 2002; 45:70-75.

26. Smud D, Kekez T, Majerovic M, Smud S. Hemorrhoids: diagnosis and treatment options, LijeVjesn, 2005; 127: 129-133.

27. Ziegler-Graham K. Estimating the prevalence of limb loss in the United States: 2005 to 2050, Archives of Physical Medicine and Rehabilitation, 2008 Mar; 


\section{9:422-429}

28. Soomro N, Bibi R, Ahmed SI, Brigitte Kamran B, Minhas MA, Siddiqui KY. Epidemiology of amputation; Professional Med J. 2013; 20: 261-5.

29. Ngim N E, Ndifon WO, Udosen A M, Ikpeme I A, Isiwele E. Lower limb amputation in diabetic foot disease: experience in a tertiary hospital in southern Nigeria, African J Diabetes Med. 2012 ; 20,13-23.

30. Russell TA. Fractures of the tibial diaphysis. Orthopedic knowledge upto date trauma Vol I, Rosemont IL, American Academy of Orthopedic Surgeons, 1996; P 171-179.

31. Zalavras CG, Marcus RE, Levin LS, Patzakis MJ. Management of open fractures and subsequent complications, J Bone Joint Surg. 2007, 89:884-895.

32. Adnan RM, Zia MI, Khan R, Ahmed S, Amin J,Danish $\mathrm{KF}$. Frequency of femoral fractures; comparison in patients less than and more than $\mathbf{4 0}$ years of age, Professional Med J. 2012; 19:911-914.

33. Sela Y, Hershkovich O, Sher-Lurie N, Schindler A, Givon U. Pediatric femoral shaft fractures: treatment strategies according to age--13 years of experience in one medical centre, J Orthop Surg Res. 2013; 80:23.

34. Miyamoto RG, Kaplan KM, Levine BR, Egol KA, Zuckerman JD. Surgical management of hip fractures: an evidence-based review of the literature, J. Am Acad Orthop Surg. 2008; 16:596-607.
35. Naz Z, Anjum S, Raza M. Correlation between agelinked serum PSA in normal subjects and patients of BPH and carcinoma prostate. Professional Med J. 2013; 20:13-18.

36. Fatima I, Nigar S, Khalid Hasan MK, Prostate cancer in different hospitals of Karachi, Professional Med J 2014;21: 514-518.

37. Chan M, Stampfer MJ, Giovannucci EL, What causes prostate cancer? A brief summary of the epidemiology, Semi Can Biol, 1998; 8; 263-273.

38. Stoller ML, Bolton DM. Urinary stone disease in JW Smith's General Urology, 17th ed. McGrawhill New Dehli, 2009: 246-277.

39. Hussain M, Rizvi SA, Askari H, Sultan G, Lal M, Ali B, Naqvi SA. Management of stone disease: 17 years experience of a stone clinic in a developing country, J Pak Med Assoc, 2009; 59:843-846.

40. Chukwudi O. Okorie,1,2 Louis L. Pisters, 3 and Ping Liu4, Longstanding hydrocele in adult Black Africans, Niger Med J. 2011;52: 173-176.

41. Siddiqui EH, Siddiqui S, Rasool G, Khan N. Scrotal pathologies. Professional Med. J. 2013; 20(6): 924-928.

42. Roos NP, Roos LL: Surgical rate variations: do they reflect the health or social economic characteristics of the population? Med Care, 1982; 20:945-958.

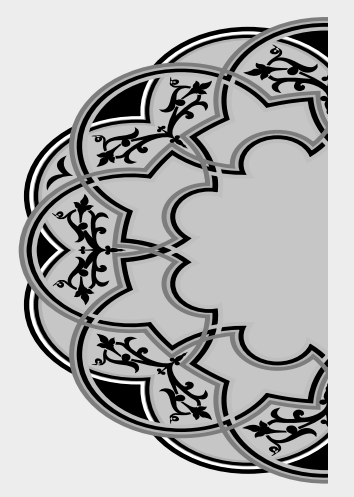

\section{“Don't just be good to others. Be good to yourself too."}

Unknown

\section{AUTHORSHIP AND CONTRIBUTION DECLARATION}

\begin{tabular}{|c|l|l|l|}
\hline Sr. \# & \multicolumn{1}{|c|}{ Author-s Full Name } & \multicolumn{1}{|c|}{ Contribution to the paper } & Author=s Signature \\
\hline 1 & Dr. Farhan Rathore & Main Author \\
2 & Dr. Usman Riaz & Co-Author \\
3 & Dr. Faizan Riaz & Co-Author \\
4 & Prof. Altaf Hussain Rathore & Co-Author \\
\hline
\end{tabular}

